\title{
Size-segregated aerosol chemical composition from an agro-industrial region of São Paulo state, Brazil
}

\author{
Cátia Gonçalves $^{1}$ (D) Bernardino R. Figueiredo ${ }^{1}$ - Célia A. Alves ${ }^{2}$. \\ Arnaldo A. Cardoso ${ }^{3}$ - Ana M. Vicente ${ }^{2}$
}

Received: 7 June 2016 / Accepted: 7 October 2016/Published online: 21 October 2016

(C) Springer Science+Business Media Dordrecht 2016

\begin{abstract}
The main objective of this research included a detailed inorganic and organic characterisation of atmospheric aerosols, to understand the changes in their composition as a result of the implementation of the Sugar and Ethanol Industry Green Protocol, in the southeastern region of Brazil. A set of 10 samples segregated into $\mathrm{PM}_{2.5}, \mathrm{PM}_{2.5-10}$ and $\mathrm{PM}_{>10}$ fractions were collected in May and July of 2014, covering the beginning of the sugarcane harvest period. The analytical methods included gravimetric determination, water-soluble ions by ion chromatography, major elements by inductively coupled plasma mass spectrometry, carbonaceous content by a thermal-optical system and organic speciation by gas chromatography-mass spectrometry. A substantially higher mean concentration $\left(57 \pm 36 \mu \mathrm{g} \mathrm{m}^{-3}\right)$ was obtained for $\mathrm{PM}_{2.5}$ in comparison with $\mathrm{PM}_{2.5-10}\left(15 \pm 6.2 \mu \mathrm{g} \mathrm{m}^{-3}\right)$ and $\mathrm{PM}_{>10}$ $\left(8.5 \pm 13 \mu \mathrm{g} \mathrm{m}^{-3}\right)$. The carbonaceous content represented, on average, approximately 18 and $21 \%$ of the particulate matter of the $\mathrm{PM}_{2.5}$ and $\mathrm{PM}_{2.5-10}$ fractions, respectively. On average, water-soluble ions accounted for 12 and $7.7 \%$ of the
\end{abstract}

Electronic supplementary material The online version of this article (doi:10.1007/s11869-016-0441-0) contains supplementary material, which is available to authorized users.

Cátia Gonçalves

catiagoncalves@ige.unicamp.br

1 Department of Geology and Natural Resources, Institute of Geosciences, University of Campinas (UNICAMP), R. João Pandiá Calógeras, 51, Campinas, São Paulo 13083-870, Brazil

2 CESAM, Department of Environment, University of Aveiro, 3810-193 Aveiro, Portugal

3 Department of Analytical Chemistry, Institute of Chemistry, Júlio de Mesquita Filho state University of São Paulo, Araraquara, São Paulo 14800-900, Brazil
$\mathrm{PM}_{2.5}$ and $\mathrm{PM}_{2.5-10}$ mass, respectively. With the implementation of the Green Protocol, a decrease of biomass burning ion tracers would be expected, however, this trend was not observed. With regard to major elements, aerosols from both fractions were dominated by $\mathrm{K}, \mathrm{Ca}, \mathrm{Na}$ and $\mathrm{Al}$. Concentrations of the major elements were lower than those observed in earlier studies. Organic compounds were present at higher levels in the fine than in the coarse fraction. $n$ Alkanes, $n$-alkanoic acids and polycyclic aromatic hydrocarbons related to biomass combustion showed lower concentrations than previously reported.

Keywords Water-soluble ions · Major elements · Organic speciation · São Paulo state $\cdot$ Brazil

\section{Introduction}

The central region of São Paulo state is occupied by a large area for sugarcane cultivation. This study was carried out in Araraquara, a city located in the main region of this crop production. Araraquara's economy is based on trade, services, industry and agriculture by this order of importance. The main industrial and agricultural activities include ethanol/sugar production, cattle farming and sugarcane cultivation (SEBRAESP 2016).

The sugarcane crop expansion in São Paulo state, as in other Brazilian regions, result from the increasing demand for ethanol as a fuel source. The total sugarcane area increased in the period 2010-2015 from 5,071,205 to 5,728,285 ha in the São Paulo state (UNICA 2016). However, the common practice of pre-harvest burning of sugarcane straw emits huge amounts of particulate material, greenhouse gases and tropospheric ozone precursors to the atmosphere. According to Lara et al. (2005), $20 \mathrm{t}$ of sugarcane straw are burned per hectare, contributing to a global emission of $0.48 \mathrm{Tg}$ of carbon 
per year. Soot, which remains suspended in the air, is considered one of the causes of the high incidence of respiratory diseases in Brazil (Arbex et al. 2000). In 2002, the São Paulo state government regulated the gradual elimination of sugarcane burning: until 2021 in mechanisable areas and in non-mechanisable areas by 2031 (State Decree ${ }^{\circ} 47700$ / 2003; State Law $n^{\circ} 11241 / 2002$ ). Therefore, manual harvesting work shall continue, at least, until these dates. In order to anticipate the end of the pre-harvest burnings to 2014, the São Paulo state Secretary of Environment (SMA) and the Sugarcane Industry Union (UNICA) signed in June 2007 the Sugar and Ethanol Industry Green Protocol to promote sustainable production practices for sugarcane in the state. At the time of this study, the pre-harvest field burning accounted for approximately $11 \%$ of the total sugarcane areas in the Araraquara region, whilst in 2010 a percentage of $43 \%$ had been registered (UNICA 2016).

Previous air quality studies indicated higher concentrations of both gases (e.g. nitrogen oxides, $\mathrm{NO}_{\mathrm{x}}$ ) (Allen et al. 2011; Machado et al. 2008) and aerosol constituents, such as $\mathrm{SO}_{4}{ }^{2-}$, $\mathrm{NO}_{3}{ }^{-}, \mathrm{Cl}^{-}, \mathrm{Na}^{+}, \mathrm{K}^{+}, \mathrm{NH}_{4}{ }^{+}, \mathrm{Mg}^{2+}$ and $\mathrm{Ca}^{2+}$ (Allen et al. 2004), during the harvest than in the non-harvest period. Although the few studies available in the region have shown that agroindustrial activities lead to important emissions of organic compounds to the lower troposphere, such as polycyclic aromatic hydrocarbons (PAH) (Andrade et al. 2010), water-soluble organic carbon (WSOC) (Souza 2011) and sugars (Scaramboni et al. 2015; Urban et al. 2014, 2016). The researches devoted to the organic speciation are still very scarce. The organic contribution was estimated to be about $62 \%$ of the aerosol emitted during sugarcane burning (Allen et al. 2010).

In this transition period, the particulate matter (PM) sources are expected to experience some changes. A reduction of sugarcane burning, and an increase of mechanised cutting and road transport, may lead to a decrease in concentrations of tracers from biomass combustion, and to an enhancement of both mineral dust resuspension and vehicular emissions.

The present research aimed to (i) accomplish a detailed chemical characterisation of size segregated inorganic and organic compounds during the harvest period, (ii) understand the changes in the aerosol composition due to the implementation of the Sugar and Ethanol Industry Green Protocol and (iii) understand the influence of changes in anthropogenic activities on the atmospheric particulate matter in the southeastern region of Brazil.

\section{Materials and methods}

\section{Sampling details}

Araraquara is a city with 226,508 inhabitants located within the sugarcane growing region of São Paulo state (IBGE 2016)
(Fig. 1). A total of 10 samples were collected from May 20 to 25 and from July 14 to 18 of 2014, covering the beginning of the harvest period. Sampling was performed with a highvolume sampler (Model TE-5000, Tisch Environmental, Inc.), operating at a flow rate of $1.12 \mathrm{~m}^{3} \mathrm{~min}^{-1}$. The aerosol samples were collected into three size fractions $\left(\mathrm{PM}_{2.5}, \mathrm{PM}_{2.5-}\right.$ 10 and $\mathrm{PM}_{>10}$ ) at the São Paulo State University (UNESP) campus $\left(21^{\circ} 48^{\prime} 50^{\prime \prime} \mathrm{S}, 48^{\circ} 12^{\prime} 07^{\prime \prime} \mathrm{W}\right)$, in a suburban area, $\sim 4 \mathrm{~km}$ southwest of the Araraquara City. The equipment was installed on the roof of a building, at $\sim 5 \mathrm{~m}$ above ground level. Particulate matter was collected on quartz fibre filters (Whatman) for 24-h periods. After collection, filters were stored in a freezer $\left(\right.$ at $\left.-14{ }^{\circ} \mathrm{C}\right)$ prior to analysis.

The acquisition of meteorological parameters (temperature, relative humidity, wind direction) was performed continuously by a meteorological station near the sampler. The data were stored using a CR10 datalogger (Campbell Scientific, Inc.) with attached multiplexers.

\section{Analytical methods}

The gravimetric determination was performed with a microbalance (Sartorius CP225D) after 24-h equilibration in a room with controlled temperature and relative humidity $\left(20 \pm 2{ }^{\circ} \mathrm{C}\right.$, $50 \pm 5 \%$ ). Quartz fibre filters used in this study were placed in an oven at $500{ }^{\circ} \mathrm{C}$ for $6 \mathrm{~h}$, to remove organic contamination. Filter weight before and after sampling was obtained as the average of several measurements, when observed variations were less than $5 \%$. The gravimetric measurements included the three size fractions $\left(\mathrm{PM}_{2.5}, \mathrm{PM}_{2.5-10}\right.$ and $\left.\mathrm{PM}_{>10}\right)$, but due to the lower loads of the super-coarse fraction $\left(\mathrm{PM}_{>10}\right)$, together with the fact that legislation refers to inhalable particles, only the fine $\left(\mathrm{PM}_{2.5}\right)$ and coarse $\left(\mathrm{PM}_{2.5-10}\right)$ fractions were subjected to chemical determinations.

The determination of water soluble ions was carried out by ion chromatography (IC). The solution obtained after extraction with $20 \mathrm{ml}$ of ultra-pure deionised water was filtered with PTFE syringe filters with a pore size of $0.45 \mu \mathrm{m}$ (VertiCleanTM) and subsequently analysed in a Dionex/ Thermo Scientific ICS-5000. The filter extracts were analysed for $\mathrm{F}^{-}, \mathrm{Cl}^{-}, \mathrm{NO}_{3}^{-}, \mathrm{SO}_{4}{ }^{2-}, \mathrm{PO}_{4}{ }^{3-}$, acetate ion $\left(\mathrm{CH}_{3} \mathrm{COO}^{-}\right)$, formate ion $\left(\mathrm{HCO}_{2}{ }^{-}\right)$, oxalate ion $\left(\mathrm{C}_{2} \mathrm{O}_{4}{ }^{2-}\right), \mathrm{Na}^{+}, \mathrm{NH}_{4}{ }^{+}, \mathrm{K}^{+}$, $\mathrm{Mg}^{2+}$ and $\mathrm{Ca}^{2+}$. Seven-point calibration curves were constructed for each ion (in triplicate), encompassing the following concentrations: $0.2,0.4,0.6,0.8,1.0,2.0$ and $3.0 \mathrm{mg}^{-1}$. The detection limits (of the mass of 8 blank filters) were estimated to be $0.17 \mu \mathrm{g} \mathrm{ml}^{-1}$ for $\mathrm{Na}^{+}, 0.01 \mu \mathrm{g} \mathrm{ml} l^{-1}$ for $\mathrm{NH}_{4}^{+}$, $0.17 \mu \mathrm{g} \mathrm{ml}^{-1}$ for $\mathrm{K}^{+}, 0.01 \mu \mathrm{g} \mathrm{ml}^{-1}$ for $\mathrm{Mg}^{2+}, 0.07 \mu \mathrm{g} \mathrm{ml}^{-1}$ for $\mathrm{Ca}^{2+}, 0.003 \mu \mathrm{g} \mathrm{ml}^{-1}$ for $\mathrm{Cl}^{-}, 0.03 \mu \mathrm{g} \mathrm{ml}^{-1}$ for $\mathrm{NO}_{3}{ }^{-}$, $0.33 \mu \mathrm{g} \mathrm{ml}^{-1}$ for $\mathrm{PO}_{4}{ }^{3-}, 0.11 \mu \mathrm{g} \mathrm{m}{ }^{-1}$ for $\mathrm{SO}_{4}{ }^{2-}$ and $0.13 \mu \mathrm{g} \mathrm{ml}^{-1}$ for $\mathrm{C}_{2} \mathrm{O}_{4}{ }^{2-}$. The quality of the measurements was judged by calculating the balance of negative and positive ions. In the $\mathrm{PM}_{2.5}$ fraction, the ion balance was close to 
Fig. 1 Location map of Araraquara City, São Paulo state

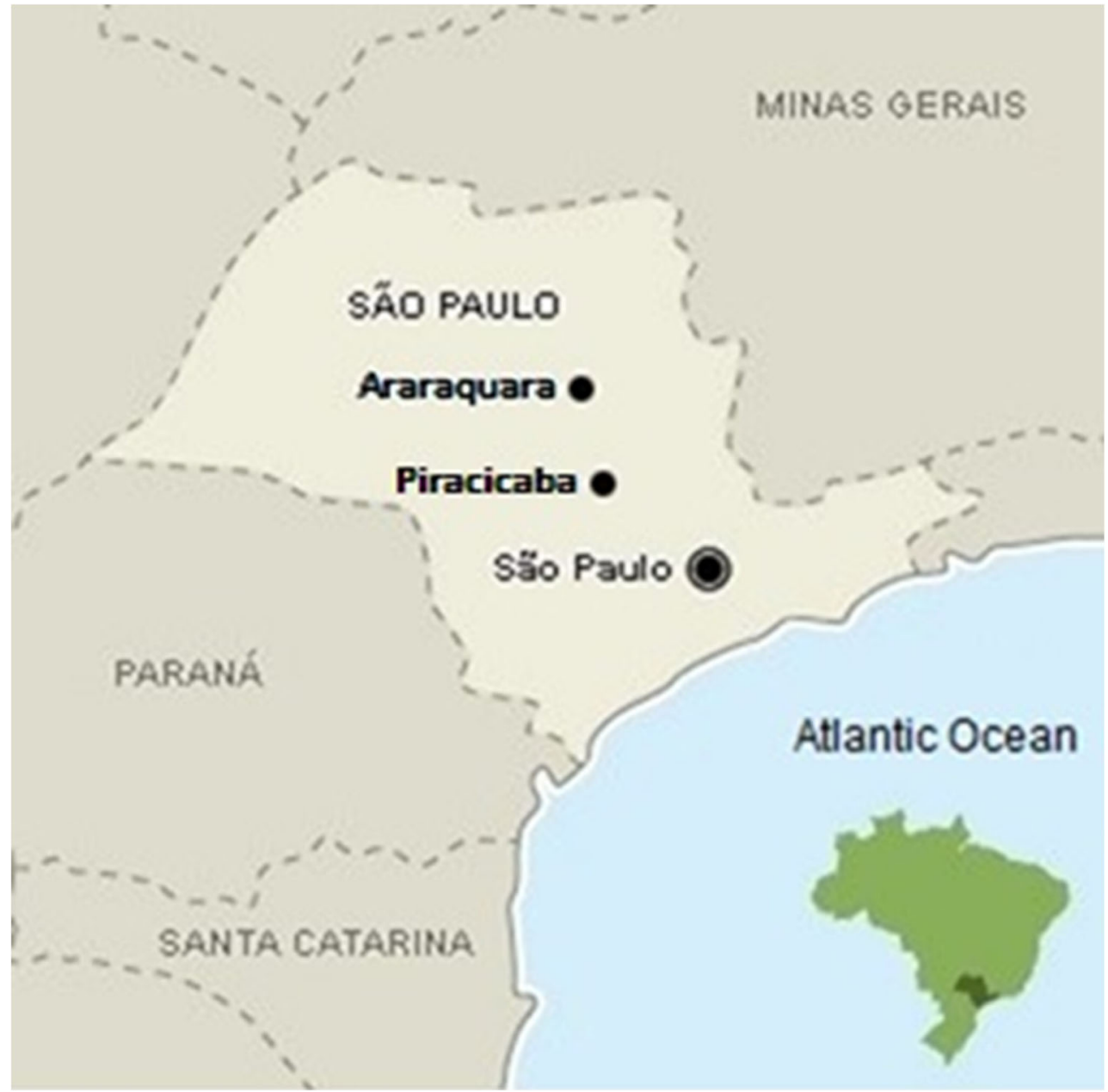

neutral. The $\mathrm{PM}_{2.5-10}$ fraction showed a deficit of anions. This deficit is probably due to unaccounted carbonates from soil resuspension.

Elements in particulate matter were determined by inductively coupled plasma mass spectrometry (ICP-MS) equipped with collision cell technology (CCT) (Xseries II-Thermo Scientific), after digestion with diluted acid solution $\left(\mathrm{HNO}_{3}\right.$, $1 \%$ ). This solution was used to characterise the composition of the aerosol which is prone to solubilisation in the environment. The filters remained for $5 \mathrm{~h}$ in a mechanical shaker (115 rpm) at room temperature, for a better removal of elements to the solution. Before ICP-MS analysis, the samples were filtered with PTFE syringe filters with a pore size of $0.45 \mu \mathrm{m}$ (VertiCleanTM). Although this analytical technique allows the determination of 57 different elements, in this study, only major elements were quantified. The detection limits (of the mass of 8 blank filters) were estimated to be $0.4 \mathrm{ng} \mathrm{ml}^{-1}$ for $\mathrm{Al}, 9.0 \mathrm{ng} \mathrm{ml}^{-1}$ for $\mathrm{Ca}, 0.05 \mathrm{ng} \mathrm{ml}^{-1}$ for $\mathrm{Cu}$, $29 \mathrm{ng} \mathrm{ml}^{-1}$ for $\mathrm{Fe}, 47 \mathrm{ng} \mathrm{ml}^{-1}$ for $\mathrm{K}, 0.2 \mathrm{ng} \mathrm{ml}^{-1}$ for $\mathrm{Mg}$, $0.03 \mathrm{ng} \mathrm{ml}^{-1}$ for $\mathrm{Mn}, 2.0 \mathrm{ng} \mathrm{ml}^{-1}$ for $\mathrm{Na}, 0.002 \mathrm{ng} \mathrm{ml}^{-1}$ for $\mathrm{Pb}, 0.01 \mathrm{ng} \mathrm{ml}^{-1}$ for $\mathrm{Rb}, 0.009 \mathrm{ng} \mathrm{ml}^{-1}$ for $\mathrm{Sr}, 0.08 \mathrm{ng} \mathrm{ml}^{-1}$ for $\mathrm{Ti}$ and $0.004 \mathrm{ng} \mathrm{ml}^{-1}$ for $\mathrm{Zn}$. For quality control, all analyses were performed in triplicate (IC) and duplicate (ICP-MS). The blank values for ions and elements were subtracted from the sample results.

For the determination of the carbonaceous content, small discs with 9-mm diameter were punched out of the quartz fibre filters. The carbonaceous content (organic carbon (OC), elemental carbon (EC)) of particulate matter was measured with a homemade thermal-optical transmission system, based on the thermal desorption/oxidation of particulate carbon to $\mathrm{CO}_{2}$, which was subsequently analysed in a nondispersive infrared (NDIR) $\mathrm{CO}_{2}$ analyser, following a protocol similar to EUSAAR (European Supersites for Atmospheric Aerosol Research). This technique is described in detail in Pio et al. (2011). Controlled heating in anoxic conditions was performed to separate OC into two fractions of increasing volatility. The first fraction corresponds to the volatilisation at $T<200{ }^{\circ} \mathrm{C}$ of lower molecular weight organics $\left(\mathrm{OC}_{1}\right)$. The second fraction is related to decomposition and oxidation of higher molecular weight species at temperatures ranging from 200 to $600{ }^{\circ} \mathrm{C}\left(\mathrm{OC}_{2}\right)$. The last fraction of $\mathrm{OC}$ is identified by transmittance and corresponds to pyrolysed organic carbon (PC) produced in the previous heating steps. Separation 
between $\mathrm{OC}$ and $\mathrm{EC}$ was achieved by initially heating the filter punches under an inert atmosphere to evaporate first the $\mathrm{OC}$ fraction. The remaining fraction is sequentially evaporated/burnt under a gas flow containing $\mathrm{O}_{2}$. This last carbon fraction contains initial EC plus OC that has pyrolysed during heating under an inert atmosphere. The interference between PC and EC can be controlled by continuous evaluation of the blackening of filter using a laser beam and a photodetector measuring the filter light transmittance. This methodology was tested with the NIST (National Institute of Standards and Technology) filter standard and in an intercomparison experiment with real aerosol samples (Schmid et al. 2001), delivering OC/EC ratios between those obtained by the NIOSH (National Institute for Occupational Safety and Health) and the IMPROVE (Interagency Monitoring of Protected Visual Environments) protocols, but closer to the latter. The procedure was also compared with the EUSAAR II protocol through the analysis of samples of different types and origins (Almeida 2009).

The samples were subjected to detailed organic analysis by gas chromatography-mass spectrometry (GC-MS). Based on the previously determined OC content, two to three consecutive filters were pooled, resulting in four sets of samples for each PM fraction (ARF1 to ARF4 - $\mathrm{PM}_{2.5}$ fraction, ARG1 to ARG4- $\mathrm{PM}_{2.5-10}$ fraction). The combined portions of the filters were consecutively extracted with dichloromethane and methanol (Fisher Scientific). Both extracts were then combined, vacuum concentrated and dried under a gentle nitrogen stream. The total organic extract (TOE) was subsequently separated into five different organic fractions by flash chromatography with activated silica gel and different solvents of increasing polarity. The TOE was transferred to the top of a glass column $(30 \times 0.7 \mathrm{~cm})$ pre-packed with $1.5 \mathrm{~g}$ of silica gel (pore size $60 \AA, 230-400$ mesh, Merck Grade 9385), previously activated at $150{ }^{\circ} \mathrm{C}$ for $3 \mathrm{~h}$. Each TOE was successively washed with different mixtures of solvents and added to the silica column. The following solvents were used to elute the different compound classes: (1) $22.50 \mathrm{ml} n$-hexane (fraction 1 , aliphatics), (2) $22.50 \mathrm{ml}$ toluene- $n$-hexane (8.40:14.10) [fraction 2, polycyclic aromatic hydrocarbons (PAHs)], (3) $22.50 \mathrm{ml} n$-hexane-dichloromethane (11.25:11.25) (fraction 3 , carbonyl compounds), (4) $30.00 \mathrm{ml}$ ethyl acetate- $n$-hexane (12.00:18.00) (fraction 4, $n$-alkanols, sterols and other hydroxyl compounds) and (5) $30.00 \mathrm{ml}$ solution of pure formic acid in methanol $(4 \%, v / v)$ (fraction 5 , acids and sugars). To speed up the process, all the solvents were eluted using a gentle nitrogen stream. After elution, all the extracts were vacuum concentrated and evaporated to approximately $1 \mathrm{ml}$ using a rotary evaporator and then dried under a gentle ultrapure nitrogen flow. The detailed description of the methodology for the organic compound extraction can be found in Alves et al. (2011). The fractionated extracts were analysed with a Gas Chromatography model 6890 coupled to a quadrupole Mass Spectrometry Detector 5973 from Hewlett Packard and with a GC-MS from Shimadzu, model QP5050A, with automatic injection. Before injection, the compounds with hydroxylic groups were converted for $3 \mathrm{~h}$ at $70{ }^{\circ} \mathrm{C}$ into the corresponding trimethylsilyl derivatives by addition of $N, O$-bis(trimethylsilyl)triflouroacetamide (BSTFA): trimethylchlorosilane (TMCS) 99:1 (Supelco). The GC-MS calibration was performed with injection of about 110 standards in different concentration ranges and relative response factors calculated for each compound and for each organic class. For those with no authentic standards available, relative response factors were calculated as an average of the relative response factors from the overall homologous series or from compounds with similar chemical structure and retention time. Standards and samples were both coinjected with one internal standard: tetracosane-d50 (Sigma Aldrich). Compound identification was based on comparison of resulting spectra with mass spectra libraries (Wiley 275 and NIST MS Search 2.0), co-injection with authentic standards and analysis of fragmentation patterns. The quantitative analysis was performed by both single ion monitoring (SIM) and total ion chromatogram (TIC) methods, in two separate GC runs. The blank filters were analysed in the same way as for the samples and the data obtained were subtracted from the samples in order to obtain blank-corrected results.

The Spearman's correlation coefficient $\left(r_{\mathrm{s}}\right)$ was used to measure the strength and direction of the relationship between the different variables (Sachs 1984). Tables with complete data are attached as supplementary material (Tables $1 \mathrm{~S}, 2 \mathrm{~S}, 3 \mathrm{~S}$ and $4 \mathrm{~S}$ ).

\section{Results and discussion}

\section{Meteorological conditions, air mass trajectories and biomass burning frequency}

During the sampling period, mean temperatures ranged from 16 to $23{ }^{\circ} \mathrm{C}$. The highest precipitation volume occurred on May 22, reaching $17 \mathrm{~mm}$. During the rest of the campaign, precipitation mean values of $2 \mathrm{~mm}$ were registered. Backward trajectory analysis was carried out by applying the Hybrid Single Particle Lagrangian Integrated Trajectory (HYSPLIT) model developed by NOAA's Air Resources Laboratory (Draxler et al. 1997, 1998), which uses meteorological files from GDAS (Global Data Analysis System). Five days $(120 \mathrm{~h})$ backward trajectories ending at the sampling place were calculated using the vertical velocity option.

In São Paulo state, sugarcane harvest happens between May and November, coinciding with the low rain precipitation period. The peak of the burning season (August) coexists with the least amount of precipitation in the region (INPE 2016). Therefore, samples collected in this study represent the beginning of the dry season/harvest period. 
Figure 2 shows the paths of air masses over two different periods of the sampling campaign. In May, the Araraquara region was mostly affected by air masses with continental origin that have passed through several northern and central states of Brazil and near the border with Bolivia, before arriving at the study site (Fig. 2a). In July (Fig. 2b), the region of Araraquara was mostly affected by two backward trajectories (500 and $1500 \mathrm{~m}$ ) containing Atlantic components. However, these air masses approached from southeast, crossing southern regions of Brazil. Araraquara was also affected by a higher altitude backward trajectory $(3000 \mathrm{~m})$ with continental origin and with a path very similar to the one observed in May.

The monthly distribution of fires in São Paulo state between January and December 2014 is shown in Fig. 3, together with data from the municipality of Araraquara (INPE 2016).

In Araraquara, the number of fires increased from 2 in May, at the start of the sampling period, to 24 in July. The maximum was reached in August with 213 fires, followed by a decline until December. The monthly frequency of fires recorded by INPE (2016) for São Paulo state followed a similar trend as that obtained for the municipality of Araraquara.

\section{Particulate matter and carbonaceous content}

The PM concentrations varied between 11 and $114 \mu \mathrm{g} \mathrm{m}^{-3}$, between 8.2 and $28 \mu \mathrm{g} \mathrm{m}^{-3}$ and between 0.75 and $45 \mu \mathrm{g} \mathrm{m}^{-3}$ for the $\mathrm{PM}_{2.5}, \mathrm{PM}_{2.5-10}$ and $\mathrm{PM}_{>10}$ fractions, respectively. A substantially higher mean concentration was obtained for $\mathrm{PM}_{2.5}$ in comparison with $\mathrm{PM}_{2.5-10}$ and $\mathrm{PM}_{>10}$ (Table 1). The daily mean concentrations of $\mathrm{PM}_{2.5}\left(57 \pm 36 \mu \mathrm{g} \mathrm{m}^{-3}\right)$ and $\mathrm{PM}_{10}\left(\mathrm{PM}_{2.5}+\mathrm{PM}_{2.5-10}\right)\left(73 \pm 42 \mu \mathrm{g} \mathrm{m}^{-3}\right)$ exceeded, by 128 and $46 \%$, respectively, the values considered as standards by the World Health Organisation (WHO 2006) (24 h mean $\mathrm{PM}_{2.5}=25 \mu \mathrm{g} \mathrm{m}^{-3}$ and $24 \mathrm{~h}$ mean $\mathrm{PM}_{10}=50 \mu \mathrm{g} \mathrm{m}^{-3}$ ), which is indicative of bad atmospheric quality and a signal of alert to long-term health effects in the study region (Andrade et al. 2012; de Miranda et al. 2012). $\mathrm{PM}_{2.5}$ represented, on average, approximately $75 \%$ of the $\mathrm{PM}_{10}\left(\mathrm{PM}_{2.5}+\mathrm{PM}_{2.5-10}\right)$ mass. The $\mathrm{PM}_{10}$ concentrations obtained in this study are of the same order as those measured, over the same time period of the year, in $2002\left(103 \pm 31 \mathrm{\mu g} \mathrm{m}^{-3}\right)$ by Andrade et al. (2010) and Godoi et al. (2004) and in 2003 $\left(67 \pm 16 \mu \mathrm{g} \mathrm{m}^{-3}\right)$ by Andrade et al. (2010), but higher than the mean level reported by Oliveira et al. (2013), in 2009 $\left(26 \mathrm{\mu} \mathrm{m} \mathrm{m}^{-3}\right)$, for the harvest period. Cançado et al. (2006) and Lara et al. (2005) described $\mathrm{PM}_{2.5}$ and $\mathrm{PM}_{2.5-10}$ concentrations of $23 \pm 15 \mu \mathrm{g} \mathrm{m}^{-3}$ and $68 \pm 43 \mu \mathrm{g} \mathrm{m}^{-3}$, respectively, for Piracicaba (1997-1998), other sugarcane region. More recently, Vasconcellos et al. (2010) observed a declining trend in $\mathrm{PM}_{10}$ concentrations in Piracicaba, with $55 \pm 26 \mu \mathrm{g} \mathrm{m}^{-3}$ in 2007 and $47 \pm 30 \mu \mathrm{g} \mathrm{m}^{-3}$ in 2008.

The carbonaceous content $(\mathrm{TC}=\mathrm{OC}+\mathrm{EC})$ represented, on average, approximately 18 and $21 \%$ of the $\mathrm{PM}_{2.5}$ and $\mathrm{PM}_{2.5-}$ 10 masses, respectively (Table 1 ). The OC concentrations in
NOAA HYSPLIT MODEL

Backward trajectories ending at 1200 UTC 25 May 14 CDC1 Meteorological Data

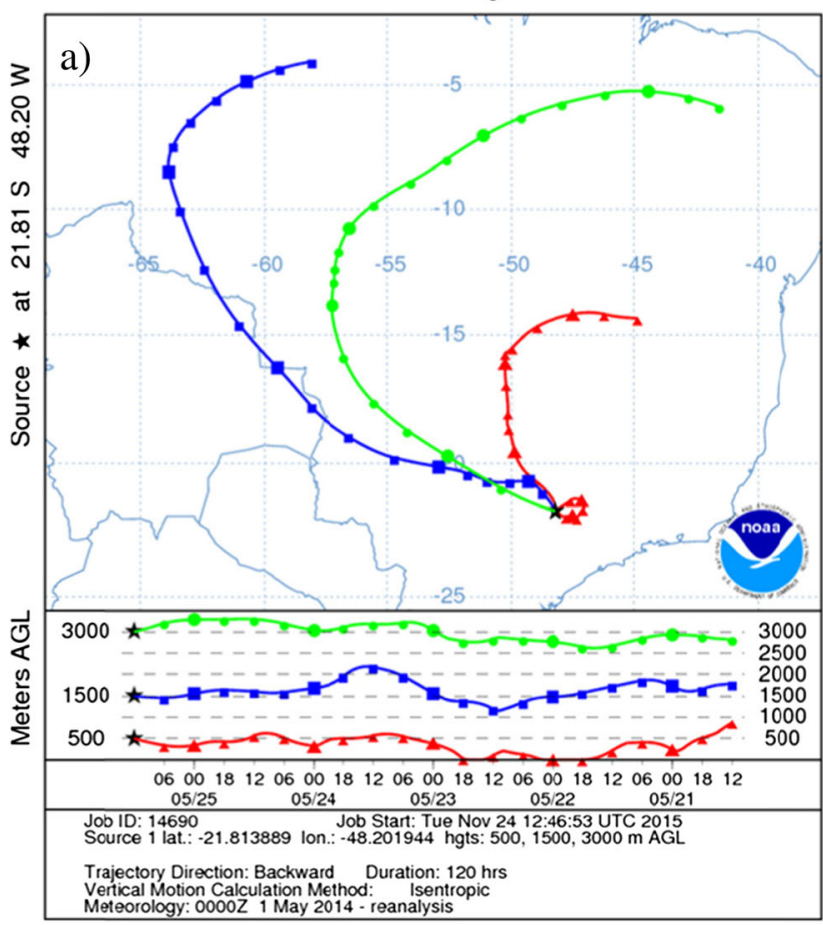

NOAA HYSPLIT MODEL Backward trajectories ending at 1200 UTC $18 \mathrm{Jul} 14$ CDC1 Meteorological Data

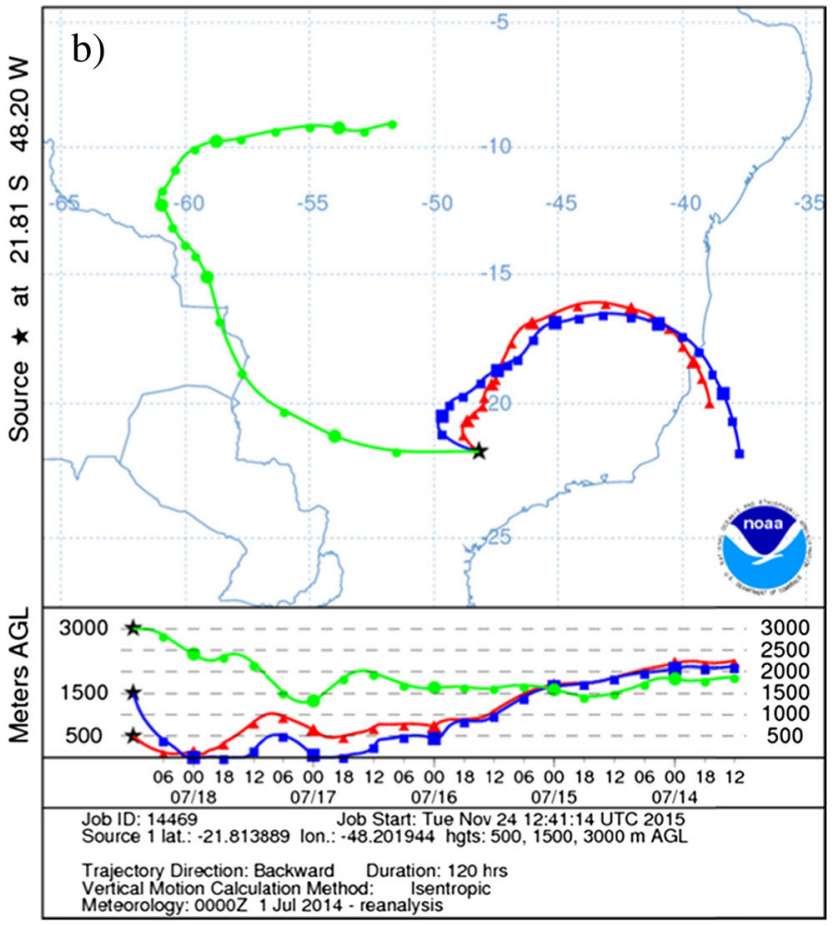

Fig. 2 HYSPLIT model backward trajectories arriving at Araraquara for two different periods of the sampling campaign. a May 2014 . b July 2014 


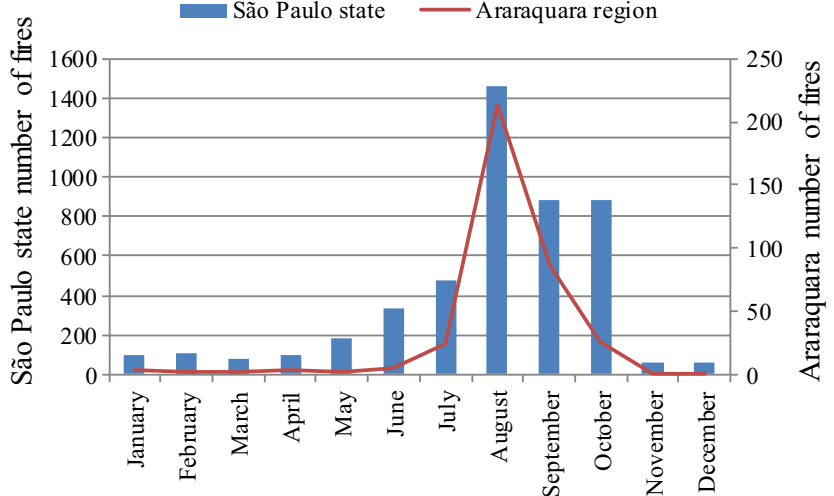

Fig. 3 Fire occurrences by month in São Paulo state and Araraquara municipality, in 2014

$\mathrm{PM}_{2.5}$ samples varied between 1.9 and $17 \mu \mathrm{g} \mathrm{m}^{-3}$, whilst EC presented values between 0.60 and $3.3 \mu \mathrm{g} \mathrm{m}^{-3}$. In the $\mathrm{PM}_{2.5-}$ ${ }_{10}$ fraction, OC ranged from 1.5 to $3.5 \mu \mathrm{g} \mathrm{m}^{-3}$. EC varied from undetectable levels to $0.42 \mu \mathrm{g} \mathrm{m}^{-3}$.

The OC-to-EC ratio in $\mathrm{PM}_{2.5}$ remained relatively constant throughout the campaign, whilst variable values were obtained for the coarse mode (Table 1). It has been reported that organic-to-elemental $\mathrm{C}$ ratios (OC/EC) measured in deciduous tree smoke samples range from 9 to 43 (average $=24$ ), whereas in grass smoke samples range from 19 to 44 (average $=31$ ) (Oros et al. 2006; Oros and Simoneit 2001). Comparatively, the ratios obtained in the present study are much lower $(4.1 \pm 1.1)$, especially in the $\mathrm{PM}_{2.5}$ fraction. This fact may be related to the decrease of the sugarcane pre-harvest burning and, on the other hand, to an increase of petroleum derived combustion emissions from mechanical harvesting processes, consequence of the Sugar and Ethanol Industry Green Protocol implementation. Moreover, it should bear in mind that sugar cane burning is characterised by very intense flaming conditions, which lead to higher EC emissions (Hall et al. 2012). High OC-EC correlations $\left(r_{\mathrm{s}}=0.879\right)$ in the $\mathrm{PM}_{2.5}$ fraction indicates that the relative rates of $\mathrm{EC}$ and $\mathrm{OC}$ would be proportional to each other and that both carbonaceous species would have common sources and transport processes. In the $\mathrm{PM}_{2.5-10}$ fraction, a weak correlation between $\mathrm{OC}$ and $\mathrm{EC}$ $\left(r_{\mathrm{s}}=0.563\right)$ was obtained, indicating the contribution of different sources (e.g. soil resuspension). These observations make sense if we consider that the majority of particles resulting from biomass burning were reported to be less than $2.5 \mu \mathrm{m}$ in diameter (Ferge et al. 2005; Hedberg et al. 2002).

Average concentrations of PM, OC, EC and TC and some ratios are shown in Table 1.

\section{Inorganic speciation}

Water-soluble ions accounted for about 3.4 to $26 \%$ of the $\mathrm{PM}_{2.5}$ concentrations, averaging $12 \%$. In the $\mathrm{PM}_{2.5-10}$ fraction, they represented about 1.8 to $15 \%$ (average $7.7 \%$ ). The average concentrations and standard deviations of watersoluble ions in the $\mathrm{PM}_{2.5}$ and $\mathrm{PM}_{2.5-10}$ size fractions are presented in Table 2 and are compared with some other studies made in Araraquara, during the harvest period. Tables with complete data are attached as supplementary material (Tables 5S, 6S).

In this study, $\mathrm{NO}_{3}{ }^{-}, \mathrm{SO}_{4}{ }^{2-}, \mathrm{K}^{+}$and $\mathrm{NH}_{4}{ }^{+}$were the ionic species with the highest concentrations in $\mathrm{PM}_{2.5}$. It has been reported previously that nitrate, sulphate and ammonium are important secondary aerosol components in the region, being involved in nucleation and growth processes of particles (Allen et al. 2004; Caetano-Silva et al. 2013). On average, $87 \%$ of the $\mathrm{K}^{+}$mass was concentrated in fine particles. The samples collected in July (1070 $\mathrm{ng} \mathrm{m}^{-3}$ ) presented approximately twice the $\mathrm{K}^{+}$concentration of the samples collected in May $\left(536 \mathrm{ng} \mathrm{m}^{-3}\right.$ ) (Tables $5 \mathrm{~S}$ and $6 \mathrm{~S}$ ). According to INPE (2016), the number of fires increased from 2 to 24 between May and July 2014 in the region of Araraquara and from 181 to 481 in the São Paulo state. Moreover, $\mathrm{K}^{+}$showed a good correlation with $\mathrm{SO}_{4}{ }^{2-}$, also associated with biomass burning $\left(r_{\mathrm{s}}=0.891\right)$. The $\mathrm{K}^{+} / \mathrm{OC}$ ratio was also taken into account. In the literature, average $\mathrm{K}^{+} / \mathrm{OC}$ in $\mathrm{PM}_{2.5}$ samples from rice straw burning (field and chamber burn) around $0.22 \pm 0.12$ have been reported, whereas in samples from fresh sugarcane leaves (field burn), the same ratio was around $0.45 \pm 0.16$ (Lin et al. 2010). Comparatively, lower values $(0.11 \pm 0.04)$ were obtained in this study. The emission factors of particulate compounds from burning of a given type of biomass typically vary with combustion conditions (Andreae and Merlet 2001). Likewise, $\mathrm{K}^{+}$and $\mathrm{OC}$ emissions are affected by the fire temperature and the combustion stage (i.e. smouldering and flaming phases) (e.g. Echalar et al. 1995; Khalil and Rasmussen 2003). The presence of $\mathrm{K}^{+}$confirms that a significant part of these particles originated from biomass burning. The ammonium concentrations observed in the $\mathrm{PM}_{2.5}$ fraction can be explained, at least in part, by the production of $\mathrm{NH}_{3}$ from the bacterial metabolism in the remaining plant debris from the mechanical harvesting process and/or fertilisers added to the soil. Moreover, the $\mathrm{NH}_{3}$ can be also emitted during biomass burning processes (Machado et al. 2008). The dominant ions in coarse particles were $\mathrm{NO}_{3}{ }^{-}, \mathrm{Cl}^{-}, \mathrm{SO}_{4}{ }^{2-}, \mathrm{Ca}^{2+}, \mathrm{Mg}^{2+}$,

Table 1 Size segregated PM, OC, EC and TC concentrations (average \pm standard deviation, $\mu \mathrm{g} \mathrm{m}^{-3}$ ) and some ratios

\begin{tabular}{lllll}
\hline & $\mathrm{PM}_{2.5}$ & $\mathrm{PM}_{2.5-10}$ & $\mathrm{PM}_{10}$ & $\mathrm{PM}_{2.5} / \mathrm{PM}_{10}(\%)$ \\
\hline $\mathrm{PM}$ & $57 \pm 36$ & $15 \pm 6.2$ & $8.5 \pm 13$ & $75 \pm 10$ \\
$\mathrm{OC}$ & $7.3 \pm 5.3$ & $2.4 \pm 0.61$ & & \\
$\mathrm{EC}$ & $1.7 \pm 0.93$ & $0.17 \pm 0.18$ & & \\
$\mathrm{TC}$ & $8.9 \pm 6.1$ & $2.6 \pm 0.73$ & & \\
OC/EC & $4.1 \pm 1.1$ & $23 \pm 37$ & & \\
TC/PM (\%) & 18 & 21 & & \\
\hline
\end{tabular}


Table 2 Average concentrations and standard deviations ( $\mathrm{ng} \mathrm{m}^{-3}$ ) for water-soluble ions in fine and coarse particles

\begin{tabular}{|c|c|c|c|c|c|c|c|c|}
\hline & \multicolumn{2}{|l|}{ This study } & \multicolumn{3}{|c|}{ Paterlini 2007} & \multirow{2}{*}{$\begin{array}{l}\text { Vasconcellos } \\
\text { et al. } 2007 \\
\mathrm{PM}_{10}\end{array}$} & \multicolumn{2}{|c|}{ Allen et al. 200} \\
\hline & $\mathrm{PM}_{2.5}$ & $\mathrm{PM}_{2.5-10}$ & $\mathrm{PM}_{<2.5}$ & $\mathrm{PM}_{>2.5}$ & $\mathrm{PM}_{10}$ & & $\mathrm{PM}_{<3.5}$ & $\begin{array}{l}\mathrm{PM}_{3.5} \\
10\end{array}$ \\
\hline $\mathrm{Na}^{+}$ & $97 \pm 86$ & $120 \pm 112$ & 80 & 163 & 238 & $340 \pm 80$ & 99 & 136 \\
\hline $\mathrm{NH}_{4}^{+}$ & $401 \pm 216$ & $22 \pm 18$ & 656 & 179 & 1076 & $800 \pm 470$ & 278 & 37 \\
\hline $\mathrm{K}^{+}$ & $803 \pm 522$ & $123 \pm 54$ & 607 & 698 & 1242 & $1590 \pm 430$ & 694 & 399 \\
\hline $\mathrm{Mg}^{2+}$ & n.d. & $88 \pm 47$ & 27 & 130 & 98 & $260 \pm 40$ & 45 & 173 \\
\hline $\mathrm{Ca}^{2+}$ & $285 \pm 185$ & $150 \pm 77$ & 155 & 834 & 472 & $730 \pm 100$ & 197 & 657 \\
\hline $\mathrm{HCO}_{2}^{-}$ & $52 \pm 62$ & $17 \pm 13$ & & & & & 127 & 74 \\
\hline $\mathrm{Cl}^{-}$ & $138 \pm 84$ & $93 \pm 103$ & 46 & 129 & 113 & $200 \pm 90$ & 114 & 222 \\
\hline $\mathrm{NO}_{3}^{-}$ & $1602 \pm 500$ & $485 \pm 342$ & 635 & 1278 & 1895 & $1950 \pm 420$ & 605 & 532 \\
\hline $\mathrm{SO}_{4}{ }^{2-}$ & $1466 \pm 518$ & $143 \pm 96$ & 1706 & 1160 & 2713 & $4120 \pm 1140$ & 1358 & 569 \\
\hline $\mathrm{C}_{2} \mathrm{O}_{4}{ }^{2-}$ & $61 \pm 46$ & $11 \pm 5$ & 181 & 8.7 & 368 & & 270 & 353 \\
\hline $\mathrm{PO}_{4}{ }^{3-}$ & $117 \pm 102$ & n.d. & 43 & 19 & 50 & $210 \pm 60$ & & \\
\hline
\end{tabular}

n.d. not detected
$\mathrm{Na}^{+}$and $\mathrm{K}^{+}$. Nitrate and chloride ions prevailed at significant concentrations in both size fractions. This is due to the fact $\mathrm{NO}_{3}{ }^{-}$and $\mathrm{Cl}^{-}$in the vapour phase $\left(\mathrm{HNO}_{3}\right.$ and $\left.\mathrm{HCl}\right)$ can be either absorbed into the coarse aerosol fraction with basic properties and may also participate in the nucleation process with ammonia vapours in the fine fraction. It would be expected that the $\mathrm{Ca}^{2+}$ concentration was greater in the $\mathrm{PM}_{2.5-10}$ fraction, but as can be seen in Tables $5 \mathrm{~S}$ and $6 \mathrm{~S}$, this is not the case. There may be another $\mathrm{Ca}^{2+}$ source that justifies a higher concentration in the fine fraction. Reid et al. (2005) argued that approximately $10 \%$ of fine-mode mass of fresh smoke is composed of trace inorganic species, most notably potassium, chlorine and calcium, which are likely present in the particle core. It has also been shown that calcium has an important function in stiffening the cell walls of a plant. It is volatilised during combustion and then condenses as submicron particles (Johansson 2002). $\mathrm{Ca}^{2+}$ and $\mathrm{Mg}^{2+}$ in coarse mode particles have a likely common origin in resuspended surface soil dust (Allen et al. 2004). These species can be resuspended by the wind or by fire-induced atmospheric turbulence and due to its size does not travel long distances, having a greater effect at local level (Allen et al. 2010). Magnesium is usually associated with calcium and sodium, and is considered a macro-soil constituent. In this study, $\mathrm{Mg}^{2+}$ was only present in the coarse fraction, presenting a good correlation with $\mathrm{Ca}^{2+}\left(r_{\mathrm{s}}=0.928\right)$ and with $\mathrm{Na}^{+}\left(r_{\mathrm{s}}=0.798\right)$. Taking into account the backward trajectories (Fig. 2), a marine influence would be expected, especially in the samples collected in July. This observation was confirmed by the $\mathrm{Na}^{+}$and $\mathrm{Cl}^{-}$higher average concentrations observed in July compared to May (Tables $5 \mathrm{~S}$ and 6S).

To compare actual results with those of other studies, it must be taken into account that different sampling techniques and analytical methods can lead to some disparities. Upon comparing the results obtained years apart (Table 2), it can be seen that the qualitative composition of the aerosol has not changed much. In the case of $\mathrm{PM}_{2.5}$, the quantitative composition was also very similar over the years. For coarse aerosols, a slight decrease in concentrations of ions emitted from biomass burning was observed. With the implementation of the Sugar and Ethanol Industry Green Protocol and the consequent reduction of pre-harvest burnings, a decrease in concentrations of ions from biomass burning would be expected. However, this trend is not observed (Table 2), due to the fact that the sugarcane straw harvested by mechanical processes is subsequently used as energy source of ethanol-producing plants. The ability of a dust collector to remove coarse particles from the exhaust flue gas is limited.

Regarding major elements, aerosols from both particulate size fractions were dominated by $\mathrm{K}, \mathrm{Ca}, \mathrm{Na}$ and $\mathrm{Al}$. Major elements, in their oxidised form, represented, on average, approximately $5.4 \%$ of the $\mathrm{PM}_{10}\left(\mathrm{PM}_{2.5}+\mathrm{PM}_{2.5-10}\right)$ mass, taking into account that a partial extraction was made with diluted acid. The results of this study are compared with those of some other studies made in Araraquara, during the harvest period in Table 3. Once again, different sampling techniques and analytical methods can lead to some disparities between studies. Tables with complete data are attached as supplementary material (Tables $7 \mathrm{~S}$ and $8 \mathrm{~S}$ ).

In this study, good correlations $\left(r_{\mathrm{s}}>0.733\right)$ were found between $\mathrm{Ca}, \mathrm{Fe}$ and $\mathrm{Al}$ in both particle size fractions. These constituents exist essentially as elements of the earth's crust. Other crustal element, $\mathrm{Ti}$, presented good correlations $\left(r_{\mathrm{s}}>0.891\right)$, in the fine fraction, with $\mathrm{Al}$ and $\mathrm{Fe}$. The soil contribution is estimated by summing all elements predominantly associated with crust minerals, assuming that they are present as oxides. $\mathrm{FeO}$ and $\mathrm{Fe}_{2} \mathrm{O}_{3}$ are assumed equally abundant. An overall factor of 1.16 is used on all stoichiometric ratios to account for minor soil constituents like $\mathrm{Na}_{2} \mathrm{O}, \mathrm{MgO}$, 
Table 3 Average concentrations and standard deviations of major elements (ng $\mathrm{m}^{-3}$ )

\begin{tabular}{|c|c|c|c|c|c|c|c|}
\hline & \multicolumn{2}{|l|}{ This study } & \multirow{2}{*}{$\begin{array}{l}\text { Oliveira etal. }^{\mathrm{a}} \\
\mathrm{TSP}\end{array}$} & \multicolumn{2}{|c|}{ Oliveira et al. 2013} & \multirow{2}{*}{$\begin{array}{l}\text { Silva et al. } \\
2015 \\
\mathrm{PM}_{2.5}\end{array}$} & \multirow{2}{*}{$\begin{array}{l}\begin{array}{l}\text { Vasconcellos } \\
\text { et al. } 2007\end{array} \\
\mathrm{PM}_{10}\end{array}$} \\
\hline & $\mathrm{PM}_{2.5}$ & $\mathrm{PM}_{2.5-10}$ & & $\mathrm{PM}_{<2}$ & $\mathrm{PM}_{2-10}$ & & \\
\hline $\mathrm{Al}$ & $145 \pm 101$ & $61 \pm 39$ & & 22 & $125 \pm 78$ & 258 & $2830 \pm 530$ \\
\hline $\mathrm{Ba}$ & $7.8 \pm 4.5$ & $4.4 \pm 2.1$ & & & & & \\
\hline $\mathrm{Ca}$ & $447 \pm 314$ & $135 \pm 124$ & $1631 \pm 1078$ & 18 & $58 \pm 33$ & 148 & \\
\hline $\mathrm{Cu}$ & $11 \pm 2$ & $2.7 \pm 1.0$ & & 0.62 & $0.65 \pm 0.26$ & 10 & $140 \pm 70$ \\
\hline $\mathrm{Fe}$ & $103 \pm 70$ & $46 \pm 27$ & $343 \pm 219$ & 16 & $114 \pm 76$ & 328 & $2830 \pm 620$ \\
\hline K & $742 \pm 382$ & $133 \pm 78$ & $1501 \pm 1118$ & 113 & $54 \pm 26$ & 1460 & \\
\hline $\mathrm{Mg}$ & $91 \pm 55$ & $53 \pm 37$ & $352 \pm 219$ & 2.6 & $22 \pm 11$ & & \\
\hline $\mathrm{Mn}$ & $13 \pm 10$ & $6.0 \pm 3.9$ & $44 \pm 32$ & 0.79 & $2.4 \pm 1.2$ & 13 & $40 \pm 10$ \\
\hline $\mathrm{Na}$ & $156 \pm 52$ & $180 \pm 100$ & & 11 & $21 \pm 19$ & & \\
\hline $\mathrm{Ni}$ & $0.29 \pm 0.13$ & $0.07 \pm 0.03$ & $0.92 \pm 0.45$ & & & 1.2 & $30 \pm 20$ \\
\hline $\mathrm{Pb}$ & $2.7 \pm 1.1$ & $0.30 \pm 0.20$ & $4.8 \pm 2.5$ & 0.71 & $0.25 \pm 0.08$ & 7.7 & $10 \pm 10$ \\
\hline $\mathrm{Rb}$ & $1.5 \pm 0.8$ & $0.21 \pm 0.12$ & & & & & \\
\hline $\mathrm{Sr}$ & $2.5 \pm 1.7$ & $1.2 \pm 0.75$ & & 0.07 & $0.40 \pm 0.19$ & & \\
\hline $\mathrm{Ti}$ & $2.4 \pm 1.3$ & $1.2 \pm 1.0$ & $18 \pm 18$ & & & 47 & $240 \pm 80$ \\
\hline $\mathrm{Zn}$ & $20 \pm 8.4$ & $2.9 \pm 1.7$ & & 3.8 & $1.7 \pm 0.64$ & 33 & $60 \pm 10$ \\
\hline $\mathrm{Zr}$ & $0.17 \pm 0.11$ & $0.02 \pm 0.02$ & $1.8 \pm 0.67$ & 0.03 & $0.18 \pm 0.11$ & & \\
\hline
\end{tabular}

${ }^{\mathrm{a}}$ Unpublished data

$\mathrm{H}_{2} \mathrm{O}$ and $\mathrm{CO}_{2}$. The final equation is the following (Appel et al. 2013; Malm et al. 1994):

$$
\begin{aligned}
\text { Soil dust contribution }= & (2.20 \times \mathrm{Al})+(2.49 \times \mathrm{Si}) \\
& +(1.63 \times \mathrm{Ca})+(2.42 \times \mathrm{Fe}) \\
& +(1.94 \times \mathrm{Ti})
\end{aligned}
$$

For the $\mathrm{PM}_{2.5-10}$ fraction, the soil dust contribution was higher $(9.7 \%)$, on average, compared to the one obtained for the $\mathrm{PM}_{2.5}$ fraction (6.5\%).

Source apportionment researches have used particle constituents such as potassium as a biomass burning tracer. In this study, a good correlation between the potassium levels determined by ICP-MS and the water-soluble form of the element was found $\left(r_{\mathrm{s}}=0.879\right)$. Thus, most of the potassium observed in the emissions of this study is water-soluble, as indicated by a $\mathrm{K}^{+} / \mathrm{K}$ ratio close to the unity in the $\mathrm{PM}_{2.5}$ fraction. Watson et al. (2001) reported $\mathrm{K}^{+} / \mathrm{K}$ ratios ranging from 0.1 in geological material profiles to 0.9 in vegetative burning emissions.

Concentrations of major elements found in this study were much lower than those in $\mathrm{PM}_{10}$ samples collected in Araraquara in July 2003 by Vasconcellos et al. (2007), particularly for $\mathrm{Fe}, \mathrm{Al}$ and $\mathrm{Cu}$. The actual levels were also lower than those found in $\mathrm{PM}_{2.5}$ collected in 2009 by Silva et al. (2015), except for $\mathrm{Ca}, \mathrm{Cu}$ and $\mathrm{Mn}$. Likewise, during the harvest period of 2010/2011, Oliveira et al. (unpublished data) gathered higher values for TSP (Table 3). Concentrations of the present study, for most elements, were also lower than those reported for both fine and coarse particles sampled in
Piracicaba (May-November, 1997), excepting K $\left(602 \pm 389 \mathrm{ng} \mathrm{m}^{-3}\right), \mathrm{Ca}\left(110 \pm 108 \mathrm{ng} \mathrm{m}^{-3}\right)$ and $\mathrm{Cu}$ $\left(6 \pm 5 \mathrm{ng} \mathrm{m}^{-3}\right)$, in the $\mathrm{PM}_{2.5}$ fraction (Lara et al. 2005).

\section{Organic speciation}

The organic fraction of the carbonaceous aerosol is formed by a complex mixture of compounds, which can be grouped into different classes. In this study, attention was focused on homologous series of aliphatic compounds ( $n$-alkanes, $n$-alkenes, $n$-alkanoic acids, $n$-alkenoic acids, and $n$-alkanedioic acids), polycyclic aromatic hydrocarbons (PAHs), lignin pyrolysis products, other acids and cellulose pyrolysis products (anhydrosugars). There are different types of diagnostic tools that allow identifying and distinguishing biogenic and anthropogenic sources of homologous compounds. The carbon preference index (CPI), the homologue with the highest concentration $\left(C_{\max }\right)$, the average chain length $(\mathrm{ACL})$ and chainlength ratios are some examples of these diagnostic tools (Alves 2008; Oros and Simoneit 2001). For $n$-alkanes, CPI is expressed as a sum of the odd carbon number homologues, over a range, divided by a sum of even carbon homologues, over the same range. For $n$-alkanoic acids, CPI is calculated inverting the ratio to have even-to-odd homologues. A table with complete data for the distinct organic classes is attached as supplementary material (Table 9S).

For all the identified and quantified organic compounds, concentrations were significantly higher, on average, for the $\mathrm{PM}_{2.5}$ fraction (192 $\pm 133 \mathrm{ng} \mathrm{m}^{-3}$ ) compared to the $\mathrm{PM}_{2.5-10}$ 
fraction $\left(40 \pm 11 \mathrm{ng} \mathrm{m}^{-3}\right)$ (Fig. 4). The results show the role of organic low-volatile gas-phase compounds in nucleation of particles. New particles are formed by condensation of semivolatile organic compounds, emitted from either biogenic or anthropogenic sources, followed by growth into small particles (Holmes 2007).

The total concentrations of $n$-alkane varied from 9.3 to $59 \mathrm{ng} \mathrm{m}^{-3}$, with an average of $34 \mathrm{ng} \mathrm{m}^{-3}$ and from 3.6 to $13 \mathrm{ng} \mathrm{m}^{-3}$, with an average of $7.9 \mathrm{ng} \mathrm{m}^{-3}$ in $\mathrm{PM}_{2.5}$ and $\mathrm{PM}_{2.5-10}$, respectively. These levels were significantly lower than those measured in the total aerosol, during the harvest period (2011), in Araraquara (458-118,070 $\mathrm{ng} \mathrm{m}^{-3}$, average $=37,999 \pm 57,712 \mathrm{ng} \mathrm{m}^{-3}$ ) by Urban et al. (2016). This significant difference can be explained by the much higher number of fires recorded in the harvest period of 2011 (INPE 2016). The $n$-alkane series comprised members from $C_{11}$ to $C_{38}$, with an odd carbon number predominance, maximising for the homologues $\geq C_{23}$. The two dominant $n$ alkanes $\left(C_{\max }\right)$ were $C_{29}$ and $C_{31}$, for both particle size fractions. The CPI for the whole range of $n$-alkanes was, on average, 2.5 in $\mathrm{PM}_{2.5}$ and 2.8 in $\mathrm{PM}_{2.5-10}$. CPI values near unity have been pointed out as indicative of anthropogenic inputs, such as emissions from incomplete combustion of fossil fuels (Schauer et al. 2002). On the other hand, values near or greater than 3 suggest a predominant origin in vascular plants (Alves 2008; Oros and Simoneit 2001). In the case of grass, and especially sugarcane burning, CPI values were found to be around 2.1 (Oros et al. 2006). CPI values obtained in this
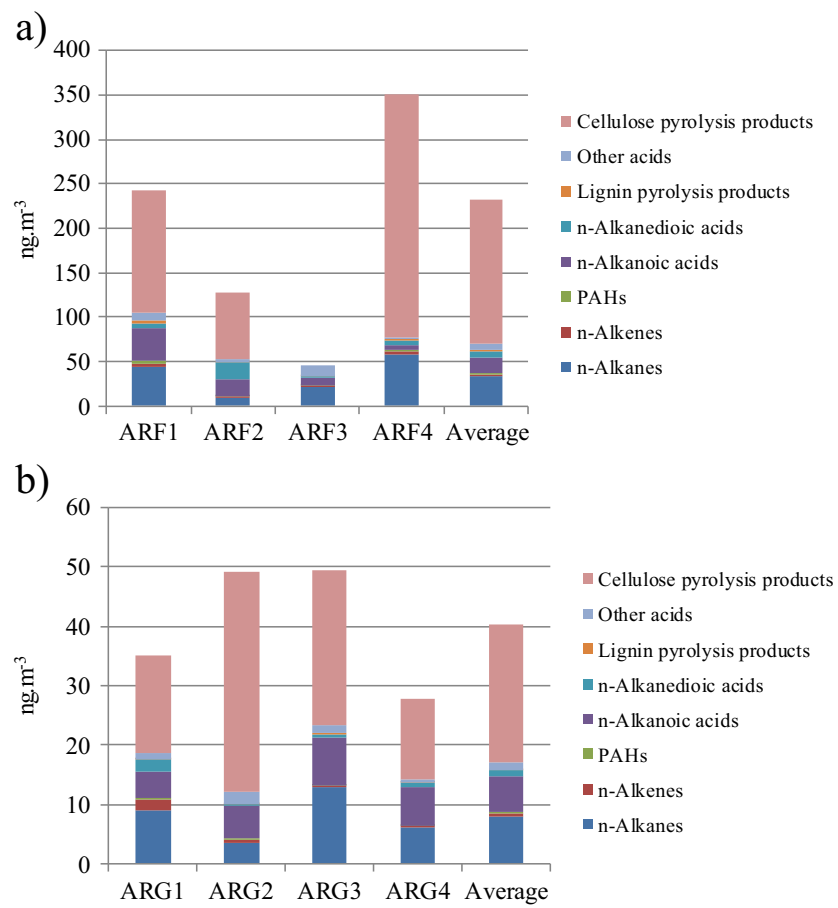

Fig. 4 Relative contributions of each organic class to the total mass of organic compounds. a $\mathrm{PM}_{2.5}$. b $\mathrm{PM}_{2.5-10}$ study are in agreement with the results obtained by Oros et al. (2006).

The aliphatic fraction also contained $n$-alkenes, ranging from $C_{14}$ to $C_{29}$. These homologues presented an even to odd $C$ number predominance, maximising at $C_{28}$ and $C_{25}$ in the $\mathrm{PM}_{2.5}$ and $\mathrm{PM}_{2.5-10}$ fractions, respectively. Total concentrations of these unsaturated aliphatics varied from 0.97 to $2.7 \mathrm{ng} \mathrm{m}^{-3}$, with an average of $1.7 \mathrm{ng} \mathrm{m}^{-3}$ in $\mathrm{PM}_{2.5}$, and from 0.20 to $1.9 \mathrm{ng} \mathrm{m}^{-3}$, with an average of $0.69 \mathrm{ng} \mathrm{m}^{-3}$ in $\mathrm{PM}_{2.5}$ 10. $n$-Alkenes are not major components in plant waxes and their origin has been inferred to be from biomass fuel and motor vehicle exhaust emissions (Abas et al. 1995). In this study, $n$-alkenes can be related to vehicle emissions due to the proximity of a highway and secondary roads with heavy traffic.

$n$-Alkanoic acids were among the most abundant compounds in all samples. These compounds are basic units in waxes and oils from plants. They ranged from $C_{8}$ to $C_{26}$, showed a strong even to odd $C$ number predominance and $C_{\max }$ at $C_{16}$ and $C_{18}$ in the $\mathrm{PM}_{2.5}$ and $\mathrm{PM}_{2.5-10}$ fractions, respectively. The CPI (whole range) was, on average, 15 in the $\mathrm{PM}_{2.5}$ fraction and 16 in the $\mathrm{PM}_{2.5-10}$ fraction. These data are consistent with the results of an earlier study on molecular tracers in organic aerosols from burning of grasses, in particular sugarcane combustion (Oros et al. 2006). Total concentrations of $n$-alkanoic acids varied from 2.9 to $36 \mathrm{ng} \mathrm{m}^{-3}$, with an average of $16 \mathrm{ng} \mathrm{m}^{-3}$ in $\mathrm{PM}_{2.5}$, and from 3.8 to $7.8 \mathrm{ng} \mathrm{m}^{-3}$, with an average of $5.5 \mathrm{ng} \mathrm{m}^{-3}$ in $\mathrm{PM}_{2.5-10}$. Once again, these values were significantly lower than those measured, in the total aerosol, during the 2011 harvest period, in Araraquara $\left(27-552 \mathrm{ng} \mathrm{m}^{-3}\right.$, average $\left.=285 \pm 191 \mathrm{ng} \mathrm{m}^{-3}\right)$, by Urban et al. (2016). Some unsaturated fatty acids, such as oleic $\left(C_{18: 1}\right)$ and linoleic $\left(C_{18: 2}\right)$ were also detected, but with lower contributions. These compounds are very reactive and, for this reason, are quite unstable and are removed very rapidly from the atmosphere by oxidation reactions with $\mathrm{OH}$ and $\mathrm{NO}_{3}$ radicals (Simoneit et al. 1990). Hence, the presence of these compounds in the aerosol can be regarded as an indicator of the aerosol age. The ratio $C_{18: 0} / C_{18: 1}$ and $C_{18: 0} / C_{18: 2}$ presented values, on average, of 80 and 6.8 and of 12 and 16 in the $\mathrm{PM}_{2.5}$ and $\mathrm{PM}_{2.5-10}$ fractions, respectively. These high ratios during the harvest period point out an aged aerosol, i.e. relatively longer residence time since its formation. This trend was also observed during the harvest period (2011), in Araraquara (46-175), in a previous study (Urban et al. 2016).

$n$-Alkanedioic acids were also present in these samples. The homologous series ranged from $C_{4}$ to $C_{10}$, maximising at $C_{4}$, in both seasons. Total concentrations varied from 0.76 to $19 \mathrm{ng} \mathrm{m}^{-3}$, with an average of $7.5 \mathrm{ng} \mathrm{m}^{-3}$, in $\mathrm{PM}_{2.5}$, and from 0.11 to $2.1 \mathrm{ng} \mathrm{m}^{-3}$, with an average of $0.9 \mathrm{ng} \mathrm{m}^{-3}$ in $\mathrm{PM}_{2.5-10}$. Although some studies have demonstrated that smoke samples from foliar fuels and deciduous trees contained $n$-alkanedioic acids ranging from $C_{4}$ to $C_{10}$ (Hays 
et al. 2002) and from $C_{16}$ to $C_{22}$ (Oros and Simoneit 2001), respectively, the $n$-alkanedioic acids have been identified in aerosols from a variety of other sources (Legrand et al. 2007; Oros and Simoneit 2001, and references therein; Wu et al. 2015). Once again, these values were significantly lower than the values obtained for the total aerosol during the harvest period (2011), in Araraquara (18-159 $\mathrm{ng} \mathrm{m}^{-3}$, average $=83 \pm 61 \mathrm{ng} \mathrm{m}^{-3}$ ) by Urban et al. (2016). $n$-Alkanedioic acids from $C_{4}$ to $C_{10}$ have also been identified in fine particle emissions from burning foliar fuels (Hays et al. 2002) and in $\mathrm{PM}_{2.5}\left(C_{4}\right.$ to $\left.C_{7}\right)$ from cereal straw burning (Zhang et al. 2007). Polycyclic aromatic hydrocarbons (PAHs) are one of the organic compound classes most studied due to its genotoxic, carcinogenic and mutagenic potential (Oros et al. 2006, and references therein). Benzo[a]pyrene is the most studied carcinogen and one of the most potent and it is often used as a toxicological prototype or surrogate for all carcinogenic polyaromatics. PAHs are toxic components of fossil fuels and primary products of incomplete combustion of organic materials (Rogge et al. 1993; Schauer et al. 1996). PAH total concentrations varied from 0.45 to $4.1 \mathrm{ng} \mathrm{m}^{-3}$, with an average of $2.1 \mathrm{ng} \mathrm{m}^{-3}$ and from 0.12 to $0.43 \mathrm{ng} \mathrm{m}^{-3}$, with an average of $0.23 \mathrm{ng} \mathrm{m}^{-3}$, in the $\mathrm{PM}_{2.5}$ and $\mathrm{PM}_{2.5-10}$ fractions, respectively. The five most abundant PAHs detected in both particle fractions were benzo[ghi]perylene, indeno[1,2,3$c d]$ pyrene, pyrene, benzo[b $+\mathrm{j}]$ fluoranthene and fluoranthene (Table 4). Concentrations of these PAHs were significantly higher in $\mathrm{PM}_{2.5}$ than in $\mathrm{PM}_{2.5-10}$. Phenanthrene, fluoranthene and pyrene, followed by anthracene and benzo[a]anthracene, were found to be the most abundant PAHs in emissions from burning of grasses (Oros et al. 2006) and Gramineae species (Simoneit 2002). In the Araraquara region, the dominant PAHs in TSP during the 2011 harvest period were retene, naphthalene, benzo[a]pyrene, fluorene and chrysene (Urban et al. 2016). Table 4 was created with data from different studies made in the Araraquara region to better understand the variations over time in PAH concentrations. It is necessary to note, once more, that different sampling techniques and analytical methods can lead to some disparities. In other studies, the dominant compounds were benzo[b $+\mathrm{k}]$ fluoranthene, fluoranthene, phenanthrene, indeno[1,2,3-cd]pyrene and benzo[ghi]perylene. PAHs are not exclusive markers of biomass combustion; however, their average concentrations have been declining over time, as can be seen in Table 4. This phenomenon is related to the increased use of mechanised harvesting in the study region, and the consequent phasing out of pre-harvest burnings. This suggests that biomass combustion for power generation emits smaller amounts of PAHs. This fact can also be confirmed by the decrease of the benzo[a]pyrene-equivalent carcinogenic power index (BaPE) (Table 4). This index has been introduced instead of the sole $\mathrm{BaP}$ since the latter is easily decomposed in reactive air (Alves 2008). This index aims at parameterising the health risk for humans related to ambient exposition to carcinogenic PAHs. The cancer risk is significant if values exceed $1.0 \mathrm{ng} \mathrm{m}^{-3}$ (WHO 2006).

The major organic components of smoke particles from biomass burning are monosaccharide derivatives (anhydrosugars) from the breakdown of cellulose and hemicellulose, such as levoglucosan, mannosan and galactosan (Oros and Simoneit 2001; Simoneit et al. 1999). As expected, among the three stereoisomers, levoglucosan was the most abundant. Concentrations of these anhydrosugars were significantly higher in $\mathrm{PM}_{2.5}\left(74-273 \mathrm{ng} \mathrm{m}^{-3}\right.$, average $\left.=162 \mathrm{ng} \mathrm{m}^{-3}\right)$ than in $\mathrm{PM}_{2.5-10}\left(14-37 \mathrm{ng} \mathrm{m}^{-3}\right.$, average $=23 \mathrm{ng} \mathrm{m}^{-3}$ ) (Table 9S). Levoglucosan, in particular, varied from concentrations of 58 to $166 \mathrm{ng} \mathrm{m}^{-3}$, with an average of $110 \mathrm{ng} \mathrm{m}^{-3}$, in the $\mathrm{PM}_{2.5}$ fraction and from 12 to $33 \mathrm{ng} \mathrm{m}^{-3}$, with an average of $21 \mathrm{ng} \mathrm{m}^{-3}$, in the $\mathrm{PM}_{2.5-10}$ fraction. These results are in agreement with the data from previous campaigns in the Araraquara region (Urban et al. 2014, 2016), in which higher levoglucosan concentration in $\mathrm{PM}_{2.5-10}\left(18-382 \mathrm{ng} \mathrm{m}^{-3}\right.$, average $\left.=138 \mathrm{ng} \mathrm{m}^{-3}\right)$ were observed during the 2011 harvest period comparing with the non-harvest period $\left(12-176 \mathrm{ng} \mathrm{m}^{-3}\right.$, average $\left.=73 \mathrm{ng} \mathrm{m}^{-3}\right)$. Several authors use the levoglucosan-to-mannosan ratio (L/M) to distinguish between hard- and softwood smoke contributions. For instance, Fine et al. (2004) reported ratios around 19-26 and 5.4 for hardwood and softwood tree species, respectively. Gonçalves et al. (2010) documented ratios in the range 10.4-34.9 for hardwoods, whilst a value of 3.0 was found for softwood. Schmidl et al. (2008) obtained ratios of 3.6 and 14.8, respectively, for soft- and hardwoods. More recently, Hall et al. (2012) reported a $\mathrm{L} / \mathrm{M}$ ratio of 10 for sugarcane burnings carried out under controlled laboratory conditions. In TSP samples collected by Urban et al. (2014), the L/M ratio varied from 1 to 22 , with an average of 9 . In this study, the $\mathrm{L} / \mathrm{M}$ ratio ranged from 3 to 9 , with an average of 6 , in the $\mathrm{PM}_{2.5}$ fraction and from 8 to 11 , with an average of 10 , in the $\mathrm{PM}_{2.5-10}$ fraction. A good linear correlation between levoglucosan and $\mathrm{K}^{+}$was observed in this study. The levoglucosan to potassium ratio $\left(\mathrm{L} / \mathrm{K}^{+}\right)$was rather constant (0.06-0.12), with an average of $0.1 \pm 0.03$, in the $\mathrm{PM}_{2.5}$ fraction. These observations are consistent with what was described by Allen et al. $(2004,2010)$ and by Urban et al. (2012) for the same region.

A rough estimate of the biomass burning contribution to OC was done as follows:

$\mathrm{OC}_{\text {biomass burning }}=[$ levoglucosan $] / 49$

where 49 is the levoglucosan/OC $\left(\mathrm{mg} \mathrm{g}^{-1}\right)$ ratio obtained by Hall et al. (2002) for sugar cane in a combustion chamber. It was found that, on average, 31 and $18 \%$ of $\mathrm{OC}$ in $\mathrm{PM}_{2.5}$ and $\mathrm{PM}_{2.5-10}$, respectively, originated from sugarcane burning. 


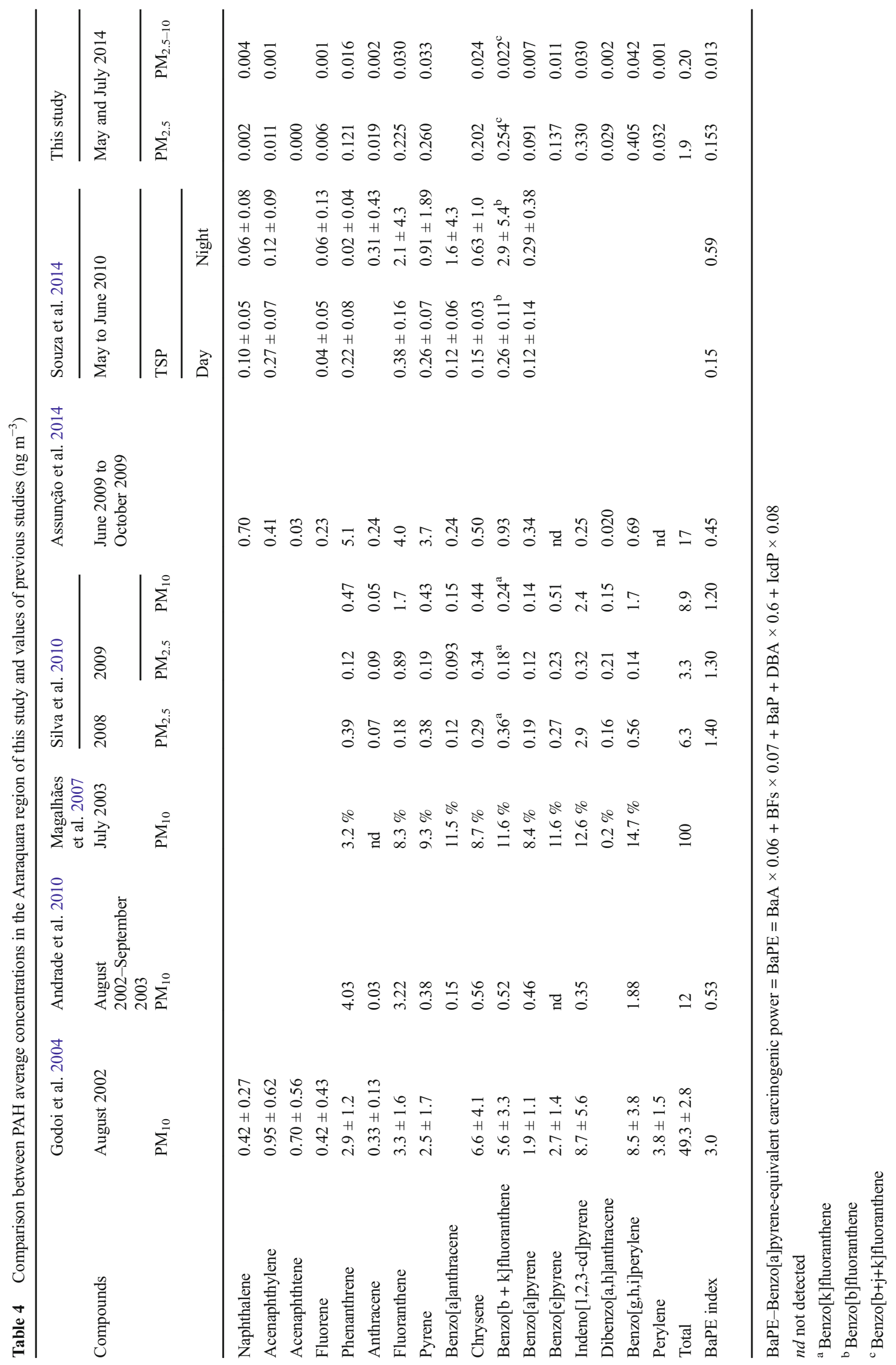




\section{Conclusions}

In this study, a detailed chemical characterisation of the atmospheric particulate matter from Araraquara, an agro-industrial region of São Paulo state, was performed. Size segregated samples were collected during the harvest period to understand the impact of implementating the Sugar and Ethanol Industry Green Protocol and the influence of changes in anthropogenic activities on aerosols of the southeastern region of Brazil.

At the beginning of the harvest period (May), the Araraquara region was mostly affected by continental air masses, starting at different northern states of Brazil. By contrast, during the July period, the region was mostly affected by backward trajectories containing Atlantic components, but approaching from the southeast, traversing southern Brazil, before arriving at the study site. The sampling period of this research coincided with the increase of the number of fires, which reached their maximum in August. Significantly higher concentrations of fine than coarse particles were obtained. Aerosol concentrations were of the same order of magnitude as those observed in the few previous studies that have been made in the region. Comparing the water-soluble ion results with other previous studies, some trends were identified. The same predominant ions were observed for both fine and coarse particles, despite presenting different concentrations: $\mathrm{NO}_{3}{ }^{-}$, $\mathrm{SO}_{4}{ }^{2-}, \mathrm{K}^{+}$and $\mathrm{NH}_{4}{ }^{+}$. With the implementation of the Sugar and Ethanol Industry Green Protocol and the consequent reduction of pre-harvest burnings, the decrease of biomass burning ions, such as $\mathrm{K}^{+}$and $\mathrm{SO}_{4}{ }^{2-}$, would be expected, but this was not observed. Aerosols from both fractions $\left(\mathrm{PM}_{2.5}\right.$ and $\mathrm{PM}_{2.5-10}$ ) also presented the same predominant major elements: K, Ca, Na and Al. Earth's crust elements, such as Ca, $\mathrm{Fe}, \mathrm{Al}$ and $\mathrm{Ti}$, showed good correlations among themselves. These elements usually appear associated with episodes of soil resuspension. The carbonaceous content represented, on average, approximately 18 and $21 \%$ of the particulate matter for the $\mathrm{PM}_{2.5}$ and $\mathrm{PM}_{2.5-10}$ fractions, respectively. It was observed that the OC/EC ratio was smaller than the values typically obtained for biomass combustion, in particular grass burning. The abundance order for the major organic groups in samples from the harvest period is as follows: cellulose pyrolysis products $>n$-alkanes $>n$-alkanoic acids, regardless of the analysed particle size fraction. Concentrations and diagnostic tools for $n$-alkanes, $n$-alkanoic acids, $n$-alkanedioic acids and PAHs presented much lower values than those found in previous studies carried out in the same area, with the exception of $n$-alkenes.

Generally, these datasets suggest that the qualitative composition of the aerosol has not changed much over the last few years. In quantitative terms, very slight variations were observed for fine particles over time. However, it seems that concentrations of coarse aerosols and their constituents have somewhat decreased. These changes may be related to the decrease of the sugarcane pre-harvest burnings, as a consequence of the implementation of the Sugar and Ethanol Industry Green Protocol. Moreover, the sugarcane straw harvested by mechanical processes is subsequently used as energy source of the ethanol-producing plants, releasing into the atmosphere compounds that may coincide with those of preharvest burnings. Whilst coarse particles are, in general, efficiently removed from the flue gas by common control devices, the performance for submicron particles may not be so effective.

\section{References}

Abas MRB, Simoneit BRT, Elias V, Cabral JA, Cardoso JN (1995) Composition of higher molecular weight organic matter in smoke aerosol from biomass combustion in Amazonia. Chemosphere 30: 995-1015. doi:10.1016/0045-6535(94)00442-W

Allen AG, Cardoso AA, Rocha GO (2004) Influence of sugar-cane burning on aerosol soluble ion composition in Southeastern Brasil. Atmos Environ 38:5025-5038. doi:10.1016/j.atmosenv.2004.06.019

Allen AG, Cardoso AA, Wiatr AG, Machado CMD, Paterlini WC, Baker $\mathrm{J}$ (2010) Influence of intensive agriculture on dry deposition of aerosol nutrients. J Braz Chem Soc 21:87-97. doi:10.1590/S010350532010000100014

Allen AG, Machado CMD, Cardoso AA (2011) Measurements and modeling of reactive nitrogen deposition in southeast Brazil. Environ Pollut 159:1190-1197. doi:10.1016/j.envpol.2011.02.002

Almeida E (2009) Aerossol carbonoso: contribuição para a sua caraterização. (Master Thesis) Aveiro University.

Alves CA (2008) Characterisation of solvent extractable organic constituents in atmospheric particulate matter: an overview. An Acad Bras Cienc 80:21-82. doi:10.1590/S0001-37652008000100003

Alves CA, Vicente A, Monteiro C, Gonçalves C, Evtyugina M, Pio C (2011) Emission of trace gases and organic components in smoke particles from a wildfire in a mixed-evergreen forest in Portugal. Sci Total Environ 409:1466-1475. doi:10.1016/j.scitotenv.2010.12.025

Andrade M, de Miranda RM, Fornaro A, Kerr A, Oyama B, de Andre PA, Saldiva P (2012) Vehicle emissions and PM2.5 mass concentrations in six Brazilian cities. Air Qual Atmos Health 5: 79-88. doi:10.1007/s11869-010-0104-5

Andrade SJ, Cristale J, Silva FS, Zocolo GJ, Marchi MRR (2010) Contribution of sugar-cane harvesting season to atmospheric contamination by polycyclic aromatic hydrocarbons (PAHs) in Araraquara city, Southeast Brazil. Atmos Environ 44:2913-2919. doi:10.1016/j.atmosenv.2010.04.026

Andreae MO, Merlet P (2001) Emission of trace gases and aerosols from biomass burning. Global Biogeochem Cy 15:955-966. doi:10.1029/2000GB001382

Appel KW, Pouliot GA, Simon H, Sarwar G, Pye HOT, Napelenok SL, Akhtar F, Roselle SJ (2013) Evaluation of dust and trace metal estimates from the Community Multiscale Air Quality (CMAQ) model version 5.0. Geosci Model Dev 6:883-899. doi:10.5194 /gmd-6-883-2013

Arbex MA, Bohm GM, Saldiva PHN, Conceicao GMS, Pope AC, Braga ALF (2000) Assessment of the effects of sugar cane plantation burning on daily counts of inhalation therapy. J Air \& Waste Manage Assoc 50:1745-1749. doi:10.1080/10473289.2000.10464211 
Assunção JV, Perquero CR, Nardocci AC, Francisco AP, Soares NS, Ribeiro H (2014) Airborne polycyclic aromatic hydrocarbons in a medium-sized city affected by preharvest sugarcane burning and inhalation risk for human health. J Air \& Waste Manag Assoc 64: 1130-1139. doi:10.1080/10962247.2014.928242

Caetano-Silva L, Allen AG, Lima-Souza M, Cardoso AA, Campos MLAM, Nogueira RFP (2013) An analysis of diurnal cycles in the mass of ambient aerosols derived from biomass burning and agroindustry. J Geophys Res Atmos 118:1-13. doi:10.1002/jgrd.50630

Cançado JED, Saldiva PHN, Pereira LAA, Lara LBLS, Artaxo P, Martinelli LA, Arbex MA, Zanobetti A, Braga ALF (2006) The impact of sugar cane-burning emissions on the respiratory system of children and the elderly. Environ Health Perspect 114:725-729. doi: $10.1289 /$ ehp. 8485

Draxler RR and Hess GD (1997) Description of the HYSPLIT_4 modeling system. NOAA Tech. Memo. ERL ARL-224, NOAA Air Resources Laboratory, Silver Spring, MD, 24.

Draxler RR, Hess GD (1998) An overview of the HYSPLIT_4 modeling system of trajectories, dispersion, and deposition. Aust Meteor Mag 47:295-308

Echalar F, Gaudichet A, Cachier H, Artaxo P (1995) Aerosol emissions by tropical forest and savanna biomass burning: characteristic trace elements and fluxes. Geophys Res Lett 22:3039-3042. doi:10.1029 195GL03170

Ferge T, Maguhn J, Hafner K, Muhlberger F, Davidovic M, Warnecke R, Zimmermann R (2005) On-line analysis of gas phase composition in the combustion chamber and particle characteristics during combustion of wood and waste in a small batch reactor. Environ Sci Technol 39:1393-1402. doi:10.1021/es049493o

Fine PM, Cass GR, Simoneit BRT (2004) Chemical characterization of fine particle emissions from fireplace combustion of woods grown in the Midwestern and western United States. Environ Eng Sci 21: 387-409. doi:10.1021/es0108988

Godoi RHM, Godoi AFL, Worobiee A, Andrade SJ, Hoog J, SantiagoSilva MR, Grieken RV (2004) Characterisation of sugar cane combustion particles in the Araraquara Region, Southeast Brazil. Microchim Acta 145:53-56. doi:10.1007/s00604-003-0126-x

Gonçalves C, Alves C, Evtyugina M, Mirante F, Pio C, Caseiro A, Schmidl C, Bauer H, Carvalho F (2010) Characterisation of PM10 emissions from woodstove combustion of common woods grown in Portugal. Atmos Environ 44:4474-4480. doi:10.1016/j.atmosenv.2010.07.026

Hall D, Wu C, Hsu Y, Stormer J, Engling G, Capeto K, Wang J, Brown S, Li H, Yu K (2012) PAHs, carbonyls, VOCs and PM2.5 emission factors for pre-harvest burning of Florida sugarcane. Atmos Environ 55:164-172. doi:10.1016/j.atmosenv.2012.03.034

Hays MD, Geron CD, Linna KJ, Smith ND, Schauer JJ (2002) Speciation of gas-phase and fine particle emissions from burning of foliar fuel. Environ Sci Technol 36:2281-2295. doi:10.1021/es0111683

Hedberg E, Kristensson A, Ohlsson M, Johansson C, Johansson PA, Swietlicki E, Vesely V, Wideqvist U, Westerholm R (2002) Chemical and physical characterization of emissions from birch wood combustion in a woodstove. Atmos Environ 36:4823-4837. doi:10.1016/S1352-2310(02)00417-X

Holmes NS (2007) A review of particle formation events and growth in the atmosphere in the various environments and discussion of mechanistic implications. Atmos Environ 41:2183-2201. doi:10.1016/j. atmosenv.2006.10.058

IBGE Instituto Brasileiro de Geografia e Estatística (2016) http://www. ibge.gov.br. Accessed February 2016

INPE - Instituto Nacional de Pesquisas Espaciais. (2016) Portal do Monitoramento de Queimadas e Incêndios: http://www.inpe. br/queimadas. Accessed February 2016

Johansson L (2002) Characterisation of particle emissions from smallscale biomass combustion. Thesis for the degree of licentiate of engineering. Chalmers University of Technology, Göteborg
Khalil MAK, Rasmussen RA (2003) Tracers of wood smoke. Atmos Environ 37:1211-1222. doi:10.1016/S1352-2310(02)01014-2

Lara LL, Artaxo P, Martinelli LA, Camargo PB, Victoria RL, Ferraz ESB (2005) Properties of aerosols from sugar-cane burning emissions in Southeastern Brazil. Atmos Environ 39:4627-4637. doi:10.1016/j. atmosenv.2005.04.026

Legrand M, Preunkert S, Oliveira T, Pio C, Hammer S, Gelencsér A, Kasper-Gieb A, Laj P (2007) Origins of $\mathrm{C}_{2}-\mathrm{C}_{5}$ dicarboxylic acids in the European atmosphere inferred from year-round aerosol study conducted at a west-east European transect. J Geophys Res 112: D23S07. doi:10.1029/2006JD008019

Lin P, Engling G, Yu JZ (2010) Humic-like substances in fresh emissions of rice straw burning and in ambient aerosols in the Pearl River Delta Region, China. Atmos Chem Phys 10:6487-6500. doi:10.5194/acp10-6487-2010

Machado CMD, Allen AG, Cardoso AA (2008) Atmospheric emission of reactive nitrogen during biofuel production of ethanol. Environ Sci Technol 42:381-385. doi:10.1021/es070384u

Magalhães D, Bruns RE, Vasconcellos PC (2007) Polycyclic aromatic hydrocarbons as sugarcane burning tracers: a statistical approach. Quim Nov. 30:577-581. doi:10.1590/S0100-40422007000300014

Malm WC, Sisler JF, Huffman D, Eldred RA, Cahill TA (1994) Spatial and seasonal trends in particle concentration and optical extinction in the United States. J Geophys Res 99:1347-1370. doi:10.1029/93 JD02916

de Miranda RM, de Fatima AM, Fornaro A, Astolfo R, de Andre PA, Saldiva P (2012) Urban air pollution: a representative survey of PM2.5 mass concentrations in six Brazilian cities. Air Qual Atmos Health 5:63-77. doi:10.1007/s11869-010-0124-1

Oliveira PL, Figueiredo BR, Arnaldo AC, Angélica RS (2013) Trace elements in atmospheric particulate matter from an agro-industrial region in southeastern Brazil. Quim Nov. 36:533-539. doi:10.1590 /S0100-40422013000400009

Oros DR, Simoneit BRT (2001) Identification and emission factors of molecular tracers in organic aerosols from biomass burning: part 2 . Deciduous trees. Appl Geochem 16:1545-1565. doi:10.1016 /S0883-2927(01)00022-1

Oros DR, Abas MR, Omar NYMJ, Rahman NA, Simoneit BRT (2006) Identification and emission factors of molecular tracers in organic aerosols from biomass burning: part 3. Grasses. Appl Geochem 21: 919-940. doi:10.1016/j.apgeochem.2006.01.008

Paterlini WC (2007) Fontes e composição das partículas atmosféricas na área urbana e rural da região central do Estado de São Paulo. PhD thesis, Universidade Estadual Paulista Júlio de Mesquita Filho, Brasil

Pio C, Cerqueira M, Harrison RM, Nunes T, Mirante F, Alves C, Oliveira C, Campa ASDL, Artínano B, Matos M (2011) OC/EC ratio observations in Europe: Re-thinking the approach for apportionment between primary and secondary organic carbon. Atmos Environ 45: 6121-6132. doi:10.1016/j.atmosenv.2011.08.045

Reid JS, Koppmann R, Eck TF, Eleuterio DP (2005) A review of biomass burning emissions part II: intensive physical properties of biomass burning particles. Atmos Chem Phys 5:799-825. doi:10.5194/acp5-799-2005

Rogge WF, Hildemann LM, Mazurek MA, Cass GR (1993) Sources of fine organic aerosol. 2. Noncatalyst and catalyst-equipped automobiles and heavy duty diesel trucks. Environ Sci Technol 27:636651. doi:10.1021/es00041a007

Sachs L (1984) Applied statistics: a handbook of techniques. Springer, New York

Scaramboni C, Urban RC, Lima-Souza M, Nogueira RFP, Cardoso AA, Allen AG, Campos MLAM (2015) Total sugars in atmospheric aerosols: an alternative tracer for biomass burning. Atmos Environ 100:185-192. doi:10.1016/j.atmosenv.2014.11.003

Schauer JJ, Kleeman MJ, Cass GR, Simoneit BRT (2002) Measurement of emissions from air pollution sources. $5 . \mathrm{C}_{1}-\mathrm{C}_{32}$ organic 
compounds from gasoline powered motor vehicles. Environ Sci Technol 36:1169-1180. doi:10.1021/es0108077

Schauer JJ, Rogge WF, Hildemann LM, Mazurek MA, Cass GR, Simoneit BRT (1996) Source apportionment of airborne particulate matter using organic compounds as tracers. Atmos Environ 30: 3837-3855. doi:10.1016/1352-2310(96)00085-4

Schmid H, Laskus L, Jürgen Abraham H, Baltensperger U, Lavanchy V, Bizjak M, Burba P, Cachier H, Crow D, Chow J, Gnauk T, Even A, Ten Brink HM, Giesen KP, Hitzenberger R, Hueglin C, Maenhaut W, Pio C, Carvalho A, Putaud JP, Toom-Sauntry D, Puxbaum H (2001) Results of the "carbon conference" international aerosol carbon round robin test stage I. Atmos Environ 35:2111-2121. doi:10.1016/S1352-2310(00)00493-3

Schmidl C, Marr IL, Caseiro A, Kotianová P, Berner A, Bauer H, Kasper Giebl A, Puxbaum H (2008) Chemical characterisation of fine particle emissions from wood stove combustion of common woods growing in mid-European Alpine regions. Atmos Environ 42:126141. doi:10.1016/j.atmosenv.2007.09.028

SEBRAESP-(2016) http://www.sebraesp.com.br/arquivos site/biblioteca/EstudosPesquisas/perfil economico municipal/municipios/Araraquara.pdf. Accessed February 2016.

Silva FS, Cristale J, André PA, Saldiva PHN, Mary RR, Marchi MRR (2010) $\mathrm{PM}_{2.5}$ and $\mathrm{PM}_{10}$ : the influence of sugarcane burning on potential cancer risk. Atmos Environ 44:5133-5138. doi:10.1016 /j.atmosenv.2010.09.001

Silva FS, Godoi RHM, Tauler R, André PA, Saldiva PHN, van Grieken $\mathrm{R}$, Marchi MRR (2015) Elemental composition of $\mathrm{PM}_{2.5}$ in Araraquara City (Southeast Brazil) during seasons with and without sugar cane burning. J Environ Prot 6:426-434. doi:10.4236 /jep.2015.65041

Simoneit BRT (2002) Biomass burning - a review of organic tracers for smoke from incomplete combustion. Appl Geochem 17:129-162. doi:10.1016/S0883-2927(01)00061-0

Simoneit BRT, Cardoso JN, Robinson N (1990) An assessment of the origin and composition of higher molecular weight organic matter in aerosols over Amazonia. Chemosphere 21:1285-1301. doi:10.1016 /0045-6535(90)90145-J

Simoneit BRT, Schauer JJ, Nolte CG, Oros DR, Elias VO, Fraser MP, Rogge WF, Cass GR (1999) Levoglucosan, a tracer for cellulose in biomass burning and atmospheric particles. Atmos Environ 33:173182. doi:10.1016/S1352-2310(98)00145-9

Souza KF, Carvalho LRF, Allen AG, Cardoso AA (2014) Diurnal and nocturnal measurements of $\mathrm{PAH}$, nitro-PAH, and oxy-PAH compounds in atmospheric particulate matter of a sugar cane burning region. Atmos Environ 83:193-201. doi:10.1016/j.atmosenv.2013.11.007
Souza ML (2011) Carbono orgânico solúvel em água no material particulado de regiões canavieiras do estado de São Paulo. Master thesis, Instituto de Química, Universidade Estadual Paulista Júlio de Mesquita Filho, São Paulo.

UNICA (União da agroindústria canavieira de São Paulo), 2016. Produtos: Cana-de-Açúcar: estatísticas. http://www.dsr.inpe. br/laf/canasat/colheita.html. Accessed February 2016.

Urban RC, Alves CA, Allen AG, Cardoso AA, Campos MLAM (2016) Organic aerosols in a Brazilian agro-industrial area: speciation and impact of biomass burning. Atmos Res 169:271-279. doi:10.1016/j. atmosres.2015.10.008

Urban RC, Alves CA, Allen AG, Cardoso AA, Queiroz MEC, Campos MLAM (2014) Sugar markers in aerosol particles from an agroindustrial region in Brazil. Atmos Environ 90:106-112. doi:10.1016/j.atmosenv.2014.03.034

Urban RC, Lima-Souza M, Caetano-Silva L, Queiroz MEC, Nogueira RFP, Allen AG, Cardoso AA, Held G, Campos MLAM (2012) Use of levoglucosan, potassium, and water-soluble organic carbon to characterize the origins of biomass-burning aerosols. Atmos Environ 61:562-569. doi:10.1016/j.atmosenv.2012.07.082

Vasconcellos PC, Balasubramanian R, Bruns RE, Sanchez-Ccoyllo O, Andrade MF, Flues M (2007) Water-soluble ions and trace metals in airborne particles over urban areas of the state of São Paulo, Brazil: influences of local sources and long range transport. Water Air Soil Pollut 186:63-73. doi:10.1007/s11270-007-9465-2

Vasconcellos PC, Souza DZ, Sanchez-Ccoyllo O, Bustillos JOV, Lee H, Santos FC, Nascimento KH, Araújo MP, Saarnio K, Teinilä K, Hillamo R (2010) Determination of anthropogenic and biogenic compounds on atmospheric aerosol collected in urban, biomass burning and forest areas in São Paulo, Brazil. Sci Total Environ 408:5836-5844 http://producao.usp.br/handle/BDPI/31016

Watson JG, Chow JC, Houck JE (2001) PM2.5 chemical source profiles for vehicle exhaust, vegetative burning, geological material, and coal burning in northwestern Colorado during 1995. Chemosphere 43:1141-1151. doi:10.1016/S0045-6535(00)00171-5

World Health Organisation (2006) - Air quality guidelines for particulate matter, ozone, nitrogen dioxide and sulfur dioxide. Global update 2005. Summary of risk assessment. WHO/SDE/PHE/OEH/06.02. WHO Press, Geneva, Switzerland.

Wu SP, Schwab J, Liu BL, Li TC, Yuan SS (2015) Seasonal variations and source identification of selected organic acids associated with $\mathrm{PM}_{10}$ in the coastal area of Southeastern China. Atmos Res 155:3751. doi:10.1016/j.atmosres.2014.11.014

Zhang Y, Shao M, Zhang Y, Zeng L, He L, Zhu B, Wei Y, Zhu X (2007) Source profiles of particulate organic matters emitted from cereal straw burning. J Environ Sci 19:167-175 